\title{
Jha, G. (2018): Fragile urban governance: Evolution, decline and empowerment of local self-government in India (Routledge, London, 384 o.)
}

\author{
VARGA LÁSZLÓ
}

\begin{abstract}
VARGA László: PhD-hallgató, Pécsi Tudományegyetem, Interdiszciplináris Doktori Iskola; 7624 Pécs, Rókus u. 2.; mlminvest@gmail.com; https://orcid.org/0000-0003-0555-331X
\end{abstract}

László VARGA: PhD student, Interdisciplinary Doctoral School, University of Pécs; Rókus u. 2., 7624 Pécs, Hungary; mlminvest@gmail.com; https://orcid.org/0000-0003-0555-331X

Az Indiai Köztársaság, mint a legnépesebb demokrácia a Földön, 1947-es megalakulása óta stabil politikai rendszerrel, kisebb-nagyobb gazdasági csavarokkal, de következetesen halad a világhatalmi státusz felé. A népességrobbanás és a globalizáció hatására lejátszódó gazdasági átalakulás a történelmileg alapvetően kistelepülési szerkezetü országban erőteljes városiasodást eredményez, ami jelentős kihívások elé állítja a városi önkormányzatokat a területfejlesztés, a közüzemi és közszolgáltatások hatékony, inkluzív és felelős megszervezésének és kivitelezésének terén. Gangadhar Jha legújabb könyvében bemutatja India városi önkormányzatiságának történetét, kitérve a függetlenség elnyerése utáni időszakban végbement hanyatlás okaira, majd a '90-es években elindult gazdasági és politikafilozófiai szerkezetváltás - melyben az ország az erősen központosított szocialista jellegű tervgazdaságról áttért a liberális piacgazdaságra - decentralizációs törekvései által kiváltott, valamint az önkormányzatok működésének helyreállítására megszületett 74. alkotmánykiegészítés tartalmára és gyakorlati megvalósulására. Az alkotmánykiegészítésre azért volt szükség, mert az önkormányzatiság kérdése alkotmányosan nem volt rendezett, annak meghatározó elemeit az alkotmány az állami szintü törvényhozások hatáskörébe utalta. Vizsgálatai alapján Jha úgy látja, hogy India városi önkormányzatiságának jelenlegi problémái három okra vezethetők vissza: a 74. alkotmánykiegészítés hiányosságaira, a 74. alkotmánykiegészítés felhatalmazásával megalkotott önkormányzati törvények hiányosságaira, valamint az alkotmányos és törvényi rendelkezések nem megfelelő végrehajtásából eredő zavarokra.

Mivel az önkormányzatok felhatalmazása és megerősítése roppant fontos az ország fejlődésének szempontjából, a szerző megoldási javaslatokat is közöl, figyelembe véve a szövetségi államok alkotmányos autonómiájának keretrend-

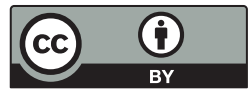


szerét. Megfelelő irányítási struktúra, hatalommegosztás, a végrehajtási és fiskális ügyek átláthatósága egyaránt részét képezik az önkormányzati működés javításának, ami jóval szélesebb és mélyebb erőfeszítést igényel, mint csupán szakirányú továbbképzéseket.

A felvetett problémát a szerző nyolc fejezetben vizsgálja. Elsőként, a hosszabb elméleti áttekintést követően, az indiai városi önkormányzatok szerepét és történetét mutatja be. A szerző szerint a mai értelemben vett önkormányzatiság fejlődése a 16-17. századi mogul uralom idején kezdődött. Az adminisztratív intézményrendszer kialakulása a Ripon-határozat 1882. május 18-i kihirdetésével indult meg. Lord Ripon India alkirályaként számos reformot vezetett be az indiai lakosság körülményeinek javítására. Az első Ripon-határozat arra kötelezte a tartományi kormányokat, hogy utaljanak pénzügyi forrásokat a helyi szintre. A második, 1882-es határozat kötelezővé tette a tartományi kormányoknak, hogy minden körzetben alapítsanak helyi szintű tanácsokat. A tanácsok létszámának legfeljebb egyharmadát tölthették be tisztviselők, a többi helyet választott helyi lakosoknak kellett adni. A Ripon-határozattal elindult önkormányzati fejlődés a függetlenség elnyerése után megalkotott alkotmánnyal, az ezt követő 1992. évi 74. alkotmánykiegészítő módosítással és az ezekből származtatott állami önkormányzati törvények megszületésével folytatódott.

A második fejezet az 1947 utáni időszakot elemzi. A területi újjászervezés óriási feladat volt, hiszen több száz, akár ezer éves múltra visszatekintő kiskirályságokat, hercegségeket, autonóm hübéri birtokokat kellett integrálni az új föderatív közigazgatási rendszerbe. A független India új alkotmánya arra törekedett, hogy az önkormányzatiság kérdéskörét törvényhozói szinten a lehető legközelebb vigye az állampolgárokhoz. A szövetségi államformában ez a szint az államok törvényhozó testületi szintje. A szubszidiaritás szempontjából kedvezőnek tűnő döntés a gyakorlatban ellenkező hatást generált. A megszületett új államok vezetői és törvényhozói egyáltalán nem fektettek hangsúlyt a helyi szint megfelelő felhatalmazására és támogatására, nem voltak érdekeltek a helyi szint megerősítésében, intézményileg gyengék és alulszervezettek, pénzügyileg pedig roppant bizonytalanok voltak, a strukturális átjárhatóság és az államok közötti megfeleltethetőség hiányáról nem is beszélve. Hatalmi holdudvarok alakultak ki országszerte, a korrupció általánossá vált, melynek legfőbb oka az elhíresült engedélytörvény (Licence Raj) volt. E szerint egy magánvállalkozás elindításához az ipari szektorban közel 80, a különböző központi és állami hivatalokból megszerzett engedéllyel kellett rendelkezni, ráadásul a kormányhivatalok megszabhatták a termelés mennyiségét és az értékesítési piacot is. Az ebben az állapotban eltöltött közel 40 év mély nyomai a mai napig is érezhetöek, főleg az állampolgári akarat inkluzivitásának hiányában és az önkormányzat hatalmi és nem szolgáltató szerepében.

A harmadik fejezetben Gangadhar Jha részletesen bemutatja, hogy miként érte el az önkormányzatiság reformjának igénye a központi kormányzat szintjét. A politikai paletta minden szintjén és színterén zajló hosszas vitákat köve- 
tően kristályosodott ki a törvényhozók számára - mind a kormánypárti koalícióban, mind az ellenzék soraiban -, hogy amíg az önkormányzatiság nem kap erős, részletes és minden államra egységesen vonatkozó alkotmányos felhatalmazást, az ország áhított gazdasági és politikafilozófiai átalakítása a szocialista tervgazdaságról a liberalizált piacgazdaságra nem lehet sikeres. A reformtörekvéseket segítette, hogy ugyanebben az időben, a '80-as évek derekán söpört végig a decentralizációs hullám a fejlett és fejlődő országok kormányzati struktúráin. A bőségesen rendelkezésre álló nemzetközi elméleti anyag és a helyi lehetőségek, szokások ötvözésével megszületett az alkotmány 74. kiegészítő módosítása, melyben a törvényalkotók létrehozták India kétágú - az egyik ágat a kistelepülési, a másikat a városi önkormányzatok alkotják - és mindkét ágban többszintes önkormányzati rendszerét.

A következő fejezet megvizsgálja azokat az állami szintü törvénymódosításokat, melyeket az alkotmányhoz való igazodás miatt hajtottak végre. Bár az állami kormányok az alkotmányos rendelkezéseket az 1993. június 1-ji határidőig beépítették önkormányzati törvényeikbe, a megfelelőségi jogszabályokban bekövetkezett változások jelentősen különböznek. Ezt az alkotmányos rendelkezések diszkrecionális jellegével és a különböző állami kormányok eltérő jogértelmezésével magyarázzák. Az alkotmánykiegészítés célja elsődlegesen az volt, hogy a választott képviselők kezébe kerüljön a döntés lehetősége a város ügyeivel kapcsolatban, ezért ők alkotják az önkormányzat testületét (wards committee). Az államok közötti különbségek abból erednek, hogy az alkotmány lehetővé teszi kiegészítő testületek létrehozását a különböző közfeladatok ellátására, amelyekben a tagok nem választottak, hanem kinevezettek. Ráadásul mind a szövetségi, mind az állami törvényhozások házába beválasztott képviselők szavazati joggal bírnak körzetük összes városi önkormányzatában.

Az ötödik fejezet az alkotmánymódosítás gyakorlati eredményeivel foglalkozik, valamint részletesen bemutatja a két, egymástól alapjaiban, felépítésében és funkcionalitásában is különböző önkormányzati rendszert. A rendszer egyik elemét a kistelepülési önkormányzatok (panchayat) alkotják. A szó eredete - a panch (öt) és az ayat (gyűlés) - visszanyúlik az ősi időkbe, amikor a település öt legbölcsebb embere gyült össze megvitatni a közösség dolgait, megoldani a problémákat. A kistelepülési önkormányzatoknak három szintje van. A legalsó szint maga a községi önkormányzat (gram panchayat), melynek testületét és a polgármestert (sarpanch) a település lakói választják öt évre. A következő szintet az alkotmány közbenső szintnek nevezi: ennek a járási önkormányzatnak (panchayat samiti) a tagjait a községi képviselők választják maguk közül. A kistelepülési önkormányzati rendszerben a legfelső a körzeti szint (zila parishad), a magyar rendszerben a megyei szintnek feleltethetö meg. A körzeti önkormányzat tagjait nem választják, az alkotmány elő́rína, hogy kik lehetnek a tagjai.

A városi önkormányzatok (municipality) rendszere ugyancsak háromszintü, de ezek a szintek semmilyen hierarchikus viszonyban nem állnak egymással, a városok csupán lakóik száma alapján különböznek, és a rájuk vonatkozó szabá- 
lyok is a városok lélekszámától függően változnak. A legkisebb egységet a 11000 és 100000 közötti lakosú kisvárosok önkormányzatai (nagar panchayat) jelentik, a második csoportba a százezer és egymillió közötti lakossal rendelkező városi önkormányzatok (nagar palika) tartoznak. A legfelső kategóriát az egymillió lakosnál többet számláló nagyvárosi önkormányzatok (mahanagar palika, angolul municipal corporation) alkotják. A képviselő-testület tagjait közvetlenül, titkos szavazással választják. A választás egymandátumos, egyszerü többségi rendszerben zajlik ötévente. A megválasztott képviselők polgármestert választanak maguk közül.

A hatodik fejezet a 74. alkotmánykiegészítés gyakorlati tapasztalatai miatt elindult újabb reformpróbálkozásokat és a helyi szintű végrehajtás segítéséhez bevezetett szövetségi kormányprogramokat mutatja be. Kitér a Jawaharlal Nehru National Urban Renewal Mission feladataira és munkájára és arra, hogy milyen költségvetési eszközökkel ösztönözték az államok kormányait olyan városi önkormányzati rendszerek kialakítására, amelyek a legjobban segítik a fokozódó, a későbbiekben részletesen kifejtett urbanizációs problémák megoldását.

A könyv utolsó két fejezete a szerző építő jellegű kritikai megjegyzéseit és a jelenlegi problémákra adott megoldási javaslatait tartalmazza. A megfogalmazott problémák a decentralizációs törekvések törvényi és végrehajtási hiányosságaiból erednek. A városi önkormányzati rendszerben a közszolgáltatások rossz minőségűek és megbízhatatlanok, a lakosság többsége számára nem elérhetőek; a költségvetés roppant hiányos és a testület által alig ellenőrzött; hiányoznak a területfejlesztési tervek; a városnövekedés ellenőrizetlen; valamint hiányosak a szervezeti kapacitások is. Az adott alkotmányos és törvényi kereten belül persze lehetne a végrehajtás sokkal jobban szervezett, hatékonyabb és az emberekhez közelibb, de sajnos a teljes kormányzati struktúra ellenérdekelt abban, hogy a végrehajtásban rejlő pénzügyi lehetőségektől megváljon.

Gangadhar Jha erős kritikával, de építő szándékkal tárja olvasói elé India többszörösen összetett, horizontálisan és vertikálisan is széttagolt önkormányzati rendszerét, különös hangsúlyt fektetve a városi önkormányzatok elemzésére. A könyv az önkormányzatiság elméleti hátterének részletes bemutatása mellett számos konkrét példát említ, melyekkel kiválóan szemlélteti a jelenlegi viszonyokat. A szerző összegzése szerint alapvető gondot jelent, hogy a közszolgáltatások zöme és a közüzemi szolgáltatók is kívül esnek az önkormányzatok hatáskörén, illetve hogy az önkormányzatoktól és egymástól egyaránt független egységként közvetlenül az állami vagy a központi kormányzatnak alárendelve működnek. Ennek eredményeként az önkormányzatok szervezeti kapacitásai roppant korlátozottak, és egységes, összehangolt irányvonalat a városok működtetésében és fejlesztésében szinte lehetetlen megvalósítani. A könyv szakmai nyelvezete kihívást jelenthet az olvasónak, de kiváló tankönyvként szolgálhat mindazoknak, akik az önkormányzatiság müködését és zsákutcáit kutatják, valamint remek összehasonlítási lehetőséget nyújt a hazaitól eltérő önkormányzati rendszerek iránt érdeklődőknek. 